\section{Synthesis and study of properties of $\mathrm{Zn}$ nanotubes}

${ }^{1,2}$ Kozlovskiy A.L.*, ${ }^{2}$ Meirimova T.Yu. ${ }^{1,2}$ Shlimas D.I., ${ }^{1,2}$ Zdorovets M.V.,

${ }^{2}$ Kadyrzhanov K.K.

${ }^{1}$ Institute of Nuclear Physics, Almaty, Kazakhstan

${ }^{2}$ L.N. Gumilyov Eurasian National University, Astana, Kazakhstan
This paper describes the method of synthesis of $\mathrm{Zn}$-based nanotubes using electrochemical deposition, as well as characterizes their morphological and conductive properties. Track membranes based on polyethylene terephthalate (PET) with a thickness of 12 microns with pore diameters of $380 \pm 10 \mathrm{~nm}$ were used as templates. Characterization of the structural features was carried out by scanning electron microscopy (SEM), energy dispersive analysis (EDA) and X-ray diffractometric analysis (XRD), and indirectly, during the study of electrical conductivity.

Calculation of the average crystallite sizes showed that the reduction in the intensity of the oxide phase $\mathrm{ZnO}$ reduces the size of the crystallites from $41.52 \mathrm{~nm}$ at $1.25 \mathrm{~V}$ to $29.34 \mathrm{~nm}$ a $1.75 \mathrm{~V}$. The number of defects, which interferes with the movement of electrons, reduced with the decreasing of the average size of crystallites in the nanotubes. The number of defects directly affected the conductive properties of $\mathrm{Zn}$ based nanotubes.

Keywords: track-etched membranes; electrochemical deposition; nanotubes.

\section{Zn-нанотүтікшелерін алу және қасиеттерін зерттеу}

\author{
1,2Козловский А.Л.*, ${ }^{2}$ Мейримова Т.Ю. \\ 1,2Шлимас Д.И., 1,23доровец М.В. \\ ${ }^{2}$ Кадыржанов К.К
}

${ }^{1}$ Қазақстан Республикасының Ядролық физика институты, Алматы қ., Қазақстан

2Л.Н. Гумилев атындағы Еуразия ұлттық университеті, Астана қ., Қазақстан *E-mail: artem88sddt@mail.ru
Мақалада электрохимиялық тұндыру арқылы Zn негізделген нанотүтікшелердің синтездеу әдісі сипатталды, сондай-ақ, олардың морфологиялық және өткізгіш қасиеттеріне мінездеме берілді. Үлгі ретінде қуыстықтардың диаметрі 380+10 нм, қалыңдығы 12 мкм полиэтилентерефталат (ПэТ) негізінде трек мембраналары пайдаланады. Құрылымдық ерекшеліктерін сипаттау растрлық электрондық микроскопия (РЭМ), энергия-дисперсиялық талдау (ЭДТ) және рентгенодифрактометриялық талдау (РДТ) әдістермен өткізіледі, және жанама электр өткізгіштігінің зерттеу барысында. Алынған нанотүтікшелердегі кристалиттердің орташа мөлшерін есептеу нәтижесінде ZnO оксидтік фазасының қарқындылығының төмендеуі кристалиттердің мөлшері 1,25 В-тағы 41,52-ден 1,75 В-тағы 29,34 нм дейін төмендейді. Алынған нанотүтікшелердегі кристаллитердің орташа мөлшерін азайту электрондардың қозғалысына кедергі болатын ақаулар санын азайтады. Ақаулар саны Zn нанотүтікшелерінің өткізгіш қасиеттеріне тікелей әсер етеді.

Түйін сөздер: тректік мембрана; электрохимиялық тұндыру; нанотүтіктер.

\section{Получение и исследование свойств Zn - нанотрубок \\ 1,2 Козловский А.Л.* , ${ }^{2}$ Мейримова Т.Ю., 1,2Шлимас Д.И., ${ }^{1,2}$ ддоровец М.В. ${ }^{2}$ Кадыржанов К.К. \\ ${ }^{1}$ Институт ядерной физики Республики Казахстан, г. Алматы, Казахстан ${ }^{2}$ Евразийский национальный университет имени Л.Н. Гумилева, г. Астана, Казахстан *E-mail: artem88sddt@mail.ru}

В данной работе описывается метод синтеза нанотрубок на основе Zn при помощи электрохимического осаждения, а также проводится характеризация их морфологических и проводящих свойств. В качестве шаблонов используются трековые мембраны на основе полиэтилентерефталата (ПЭТФ) толщиной 12 мкм сдиаметрами пор $380 \pm 10$ нм. Характеризация структурных особенностей проводится методами растровой электронной микроскопии (РЭМ), энергодисперсионного анализа (ЭДА) и рентгенодифрактометрического анализа (РСА), и, косвенно, при изучении электропроводности. Расчеты среднего размера кристаллитов показали, что снижение интенсивности пиков оксидной фазы ZnO на рентгенограмме приводит к уменьшению размеров кристаллитов с 41,52 нм для 1,25 В до 29,34 нм для 1,75 В. С уменьшением среднего размера кристаллитов в полученных нанотрубках снижается количество дефектов, которые препятствуют движению электронов. Количество дефектов напрямую влияет на проводящие свойства Zn - нанотрубок.

Ключевые слова: трековые мембраны; электрохимическое осаждение; нанотрубки. 


\title{
CHEMICAL BULLETIN
}

of Kazakh National University

http://bulletin.chemistry.kz/

UDC 53.043

http://dx.doi.org/10.15328/cb670

\section{Synthesis and study of properties of $\mathrm{Zn}$ nanotubes}

\author{
1,2Kozlovskiy A.L.*, ' ${ }^{2}$ Meirimova T.Yu., ${ }^{1,2}$ Shlimas D.I., 1,2Zdorovets M.V., ${ }^{2}$ Kadyrzhanov K.K. \\ ${ }^{1}$ Institute of Nuclear Physics, Almaty, Kazakhstan \\ ${ }^{2}$ L.N. Gumilyov Eurasian National University, Astana, Kazakhstan \\ *E-mail: artem88sddt@mail.ru
}

\section{Introduction}

At present time, significant efforts are focused on synthesis and study of properties of metal one-dimensional nanomaterials or metal nanotubes/nanowires such as $\mathrm{Au}, \mathrm{Ag}, \mathrm{Cu}, \mathrm{Fe}, \mathrm{Co}$, $\mathrm{Ni}, \mathrm{Pd}, \mathrm{Bi}, \mathrm{W}$ [1-7]. This tendency is due to prospect of their application in optoelectronics, photo electrochemistry, catalysis, medicine etc. $[8,9]$. The ability to monitor and control physical and chemical properties of such structures attract interest to them, because this property contributes to the expansion of use of nanomaterials.

There are only few works devoted to synthesis of zinc-based nanostructures along with other elements, despite a number of attractive features these structures have. For example, $\mathrm{Zn}$ is biologically safe, it has low toxicity and biocompatibility, therefore it can be applied in various configurations of nanostructures (nanowires, nanotubes, nanoparticles) [10, 11]. $\mathrm{Zn}$-based nanomaterials have semiconducting and piezoelectric properties. This phenomenon is the basis for electrochemical related sensors and transducers. Practical application of semiconductors based on zinc or zinc oxide is only limited by a lack of methods that provide control over production of nanotubes with crystal structure of walls. Zink-based nanowires were obtained in the work [12] and nanoparticles - in the work [13].

There is a variety of methods used for preparation of nanostructures based on $\mathrm{Zn}$ and $\mathrm{ZnO}$ : chemical vapor deposition of metals [3], method of arc discharge [4], laser evaporation [5] and templated synthesis $[6,7]$. The most acceptable method among them is method of templated synthesis due to satisfying requirements of stability and chemical inertness. The method of templated synthesis allows obtaining round pores with the same diameter from tens to hundreds of nanometers in template matrices, which are convenient materials for production of structurally homogeneous nano replicas.

In this paper, we describe the method of synthesis of
Zn-based nanotubes using electrochemical deposition and characterize their morphological and conductive properties. Track-etched membranes based on polyethylene terephthalate (PET) with thickness of 12 microns and pore diameters $380 \pm 10$ $\mathrm{nm}$ were used as templates. Characterization of the structural features is carried out by scanning electron microscopy (SEM), energy dispersive analysis (EDA) and X-ray diffractometric analysis (XRD), and indirectly, during the study of electrical conductivity.

Successful production of $\mathrm{Zn}$ nanotubes will give possibility of their full-scale application as semiconductor materials in electronic and optoelectronic circuits $[1,2,14,15$,] due to large width of bandgap (3.37 eV), piezoelectric properties and high energy of exciton bond (60 MeV).

\section{Experiment}

Track-etched membranes based on PET polymer matrix Hostaphan ${ }^{\circledR}$ manufactured by Mitsubishi Polyester Film (Germany) were used for producing $\mathrm{Zn}$ nanotubes by electrochemical deposition from electrolyte solution. PET film was irradiated by krypton ions using cyclotron DC- 60 with the energy of $1.75 \mathrm{MeV} /$ nucleon. UV-sensitization of irradiated track membranes was performed using UV-C lamp with a wavelength of $253.7 \mathrm{~nm}$ from each side for $30 \mathrm{~min}$. UV radiation led to photo oxidation of surface layer of polymer and allowed obtaining pores with the same diameter in a polymer. After UV sensitization, film was chemically etched from both sides in 2.2 $\mathrm{M} \mathrm{NaOH}$ aqueous solution at the temperature of $85 \pm 1^{\circ} \mathrm{C}$ for $4.5 \mathrm{~min}$, followed by neutralization in $1.0 \%$ aqueous solution of acetic acid $[16,17]$.

Electrochemical deposition in tracks of template matrix was carried out at voltage of 1.25-1.75 $\mathrm{V}$ with a step of 0.25 $\mathrm{V}$ in the potentiostatic mode. Monitoring the progress of the experiment was done by chronoamperometry on multimeter Agilent 34410A. 
Investigation of a structure and dimensions of obtained nanotubes was carried out using scanning electron microscope (SEM) Hitachi TM3030 (Japan) with microanalysis system Bruker XFlash MIN SVE (Germany) at accelerating voltage of $15 \mathrm{kV}$.

$\mathrm{X}$-ray diffractometer studies were performed on the diffractometer Bruker D8 ADVANCE (Germany) equipped with $\mathrm{X}$-ray tube with $\mathrm{Cu}$-anode and graphite monochromator on the diffracted beam. Tube operation mode was $40 \mathrm{kV}$ at $40 \mathrm{~mA}$. Diffractograms were recorded in the angle range $20-120^{\circ} 2 \theta$, step $0.03^{\circ}$ and accumulation time $9 \mathrm{~s}$.

Current source HP 66312A and ammeter Agilent34401A were used to measure the volt-ampere characteristics.

Before studying structural features of samples, the template matrix was removed by dissolving it in a hot solution of $9.0 \mathrm{M} \mathrm{NaOH}$ and then treated for $10 \mathrm{~s}$ in an ultrasonic bath to separate from polymer residues.

\section{Results and discussions}

PET-based matrix with pore density of $4.0 \mathrm{E}+07$ pores $/ \mathrm{cm}^{2}$ and thickness 12 microns was used as a template. The important feature of a templated synthesis is a possibility to control and regulate properties of obtained nanostructures due to using pores with a given geometry $[6,7,17]$. Diameter of pores of track membrane used for deposition of $\mathrm{Zn}$ nanotubes was $380 \pm 10 \mathrm{~nm}$. Figure 1 shows images of track-etched membranes after 4.5 minutes of etching with pore diameters $380 \pm 10 \mathrm{~nm}$ obtained using scanning electron microscope.

Unilateral magnetron sputtering of a gold layer (thickness of $10 \mathrm{~nm}$ ) on template matrices (Figure 1d) was done before electrochemical deposition of metal. Conductive layer was formed on the polymer as a result of magnetron sputtering in vacuum, which served as working electrode, a cathode, during deposition. Thickness of $10 \mathrm{~nm}$ allows formation of a substrate that does not cover pores entirely. It leads to the initial growth of structures along the walls during deposition process, ultimately forming hollow structures.

The electrolyte composition for producing $\mathrm{Zn}$ nanotubes is following: $\mathrm{ZnSO}_{4} \cdot 7 \mathrm{H}_{2} \mathrm{O}-360 \mathrm{~g} / \mathrm{l} ; \mathrm{NH}_{4} \mathrm{Cl}-30 \mathrm{~g} / \mathrm{l} ; 3 \mathrm{H}_{2} \mathrm{O} \cdot \mathrm{CH}_{3} \mathrm{COONa}$ $-15 \mathrm{~g} / \mathrm{L}$; ascorbic acid $-120 \mathrm{~g} / \mathrm{L}$. Deposition of metals in pores of template matrix was carried out at potential difference from 1.25 to $1.75 \mathrm{~V}$ with step $0.25 \mathrm{~V}$. Figure 2a shows dependence of amperage on the time of deposition of nanostructures during electrochemical deposition process.

It is known that the process of electrochemical deposition of metals in pores consists of 3 basic stages The first stage corresponds to the start of template pores filling that happens at $t<50 \mathrm{~s}$ in our case. This stage is characterized by a sharp drop of current, which occurs as a result of nucleation process on cathode. The straight line on figure $2 \mathrm{a}$ corresponds to the second stage; at this stage, growth of nanotubes within pores happens. Process continues until the moment, when length of the nanotube becomes equal to the thickness of template. At the third stage, after reaching surface of template, metal starts growing in three dimensions (volume growth) above surface of polymer film, forming "caps" that grow from walls of nanotubes. As a result, effective surface area of deposition increases, as does the registered current. The third stage continues until overlap of metal islands located in areas of localization of nanotubes. Finally, continuous metal layer forms on the surface of template leading to the saturation of $I$. This value of $I$ corresponds to the current of synthesis measured on metal electrode of the same

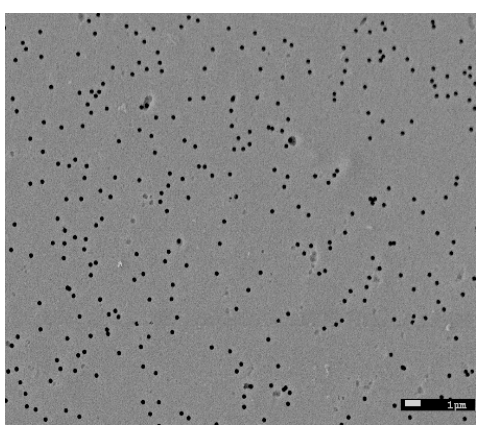

a)

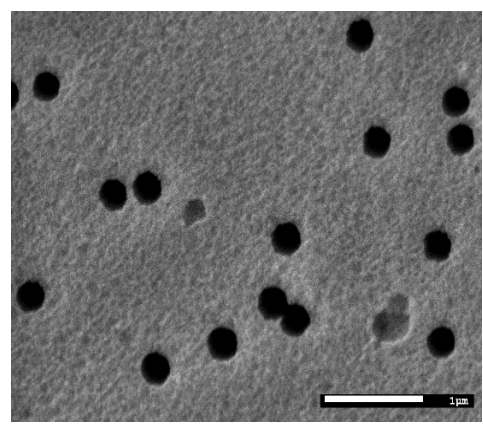

b)

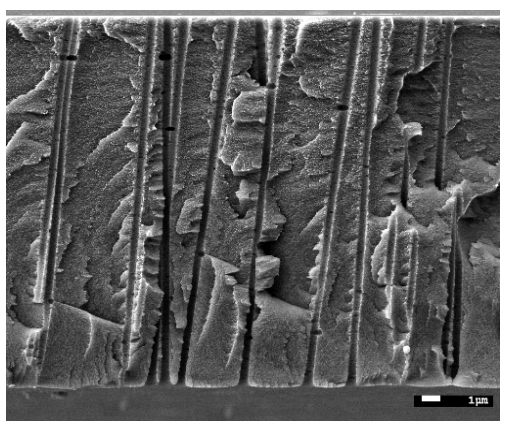

c)

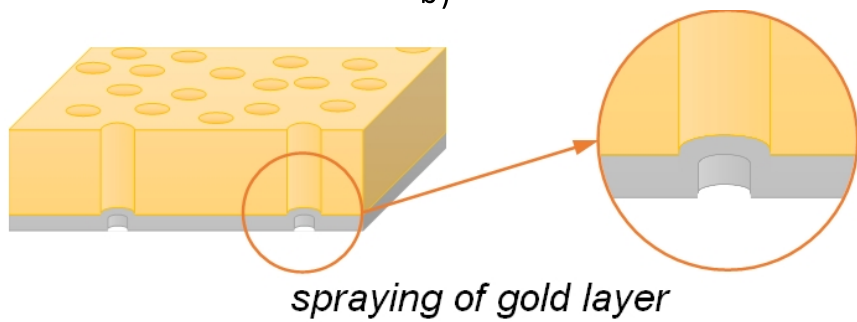

d)

Figure 1 - SEM-images of PET-film after 4.5 min of etching. The surface of track membrane $(a, b)$, a side view of the section of track membrane (c) and scheme of gold sputtering (d) 


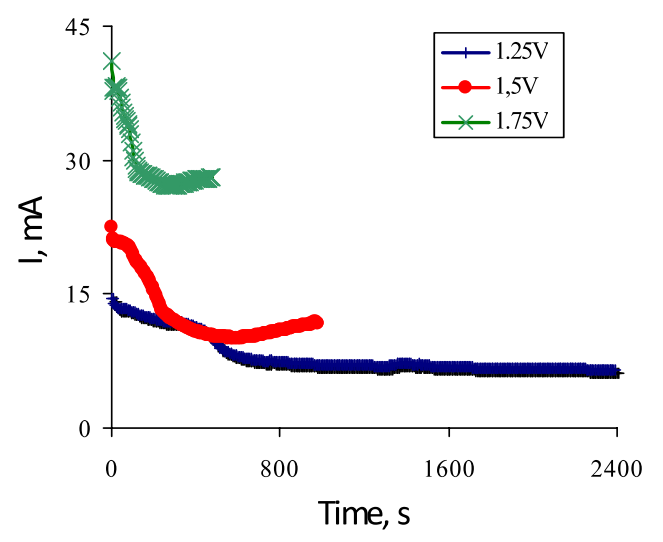

a)

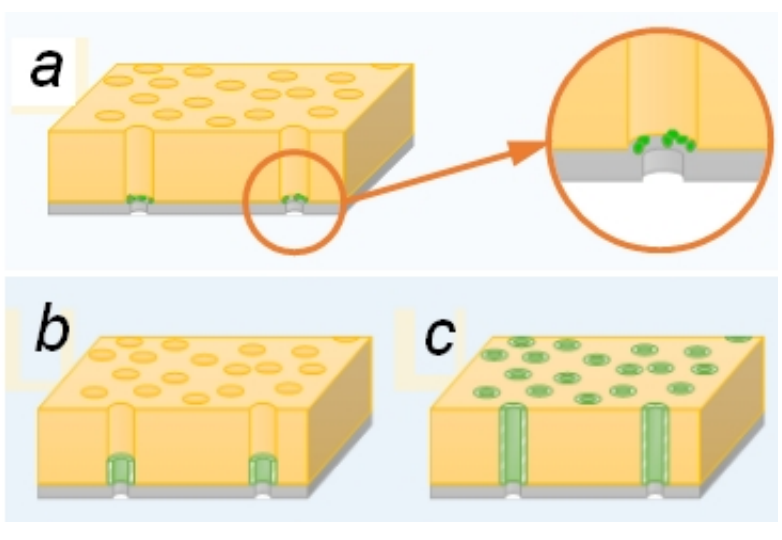

b)

Figure $\mathbf{2}$ - Chronoamperogramms of deposition process (a) and scheme of nanotubes growth (b)

area and at the same applied voltage. It should be noted, that behavior of I $(t)$ on chronoamperograms depends on parameters of deposition and shape of pores.

Calculations of volume rate of deposition were made using obtained chronoamperogramms. Determination of rate constant of deposition for potential difference allows controlling the time of template matrix filling and the height of nanostructures (Figure 3)

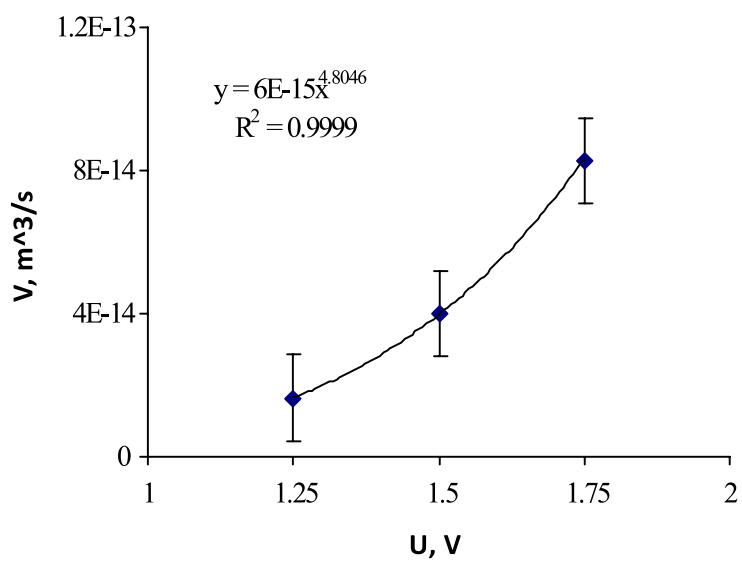

Figure 3 - Dependence of volume change rate on potential difference

The following conclusion can be made from calculations: volume rate of $\mathrm{Zn}$ deposition in pores of template matrix with diameter $380 \pm 10 \mathrm{~nm}$ increases exponentially with growth of potential difference from $1.25 \mathrm{~V}$ to $1.75 \mathrm{~V}$.

The outer diameter of nanotubes was set by diameter of matrix pores and was $380 \pm 10 \mathrm{~nm}$; the inner diameter was determined by method of gas permeability [18] to be $180 \pm 10$ $\mathrm{nm}$ and the thickness of walls of nanotubes was $100 \pm 5 \mathrm{~nm}$.

Figures $4 a, 4 c$ and $4 \mathrm{e}$ show images of $\mathrm{Zn}$ nanotubes. The height of nanotubes was determined from analysis of SEM- images to be 12 microns; diameters of nanotubes correspond to diameter of pores of template matrices. Figures $4 b, 4 d$ and $4 \mathrm{f}$ represent EDA spectra of $\mathrm{Zn}$ nanotubes deposited at different potential differences.

Table 1 shows data on atomic ratio in obtained samples.

Table 1 - Data on the atomic ratio of metals in obtained nanostructures

\begin{tabular}{|c|c|}
\hline Name of sample & Atomic ratio \\
\hline $\mathrm{Zn} 1.25 \mathrm{~V}$ & $\mathrm{Zn}_{73} \mathrm{O}_{27}$ \\
\hline $\mathrm{Zn} 1.50 \mathrm{~V}$ & $\mathrm{Zn}_{86} \mathrm{O}_{14}$ \\
\hline $\mathrm{Zn} 1.75 \mathrm{~V}$ & $\mathrm{Zn}_{100}$ \\
\hline
\end{tabular}

These data indicate the formation of oxide phase of zinc with atomic ratio $\mathrm{Zn}_{73} \mathrm{O}_{27}$ occurring as a result of deposition at the potential difference of $1.25 \mathrm{~V}$. Oxide phase is displaced with increasing applied potential difference - it happens due to a predominance of half of redox potential of $\mathrm{Zn}$ recovery $(1.6 \mathrm{~V})$ on formation of oxide phase $\mathrm{ZnO}(1.0 \mathrm{~V})$. Thus, pure zinc nanotubes without additives of oxide phases can be obtained by electrochemical deposition at potential difference of $1.75 \mathrm{~V}$.

$X$-ray diffractometer studies were carried out to identify crystal structure of $\mathrm{Zn}$ nanotubes. Diffractograms were recorded in the angle range $20-120^{\circ} 2 \theta$ with step $0.03^{\circ}$ and $9 \mathrm{~s}$ accumulation at each point. XRD experiment showed that samples have hexagonal primitive (HP) structure with lattice parameters different from reference values. Figure 5 shows $\mathrm{X}$-ray diffractograms of test samples at 1.25, 1.5 and $1.75 \mathrm{~V}$.

Presence of oxide phase $\mathrm{ZnO}$ is observed on diffractogram at $37^{\circ}, 58^{\circ}, 68^{\circ}$. A decrease in peak intensity of oxide phase $\mathrm{ZnO}$ is observed with increase of applied potential difference in crystal structure; oxide phase $\mathrm{ZnO}$ is not observed on diffractogram at potential difference $1.75 \mathrm{~V}$, which is also confirmed by 


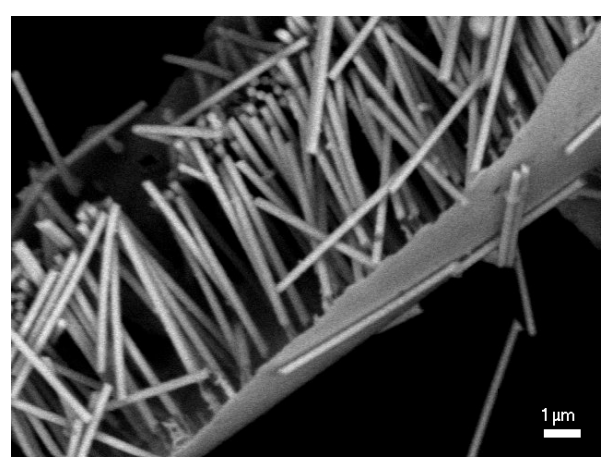

a)

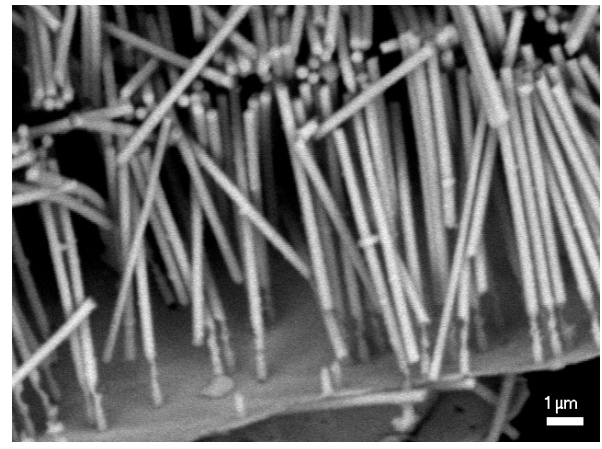

c)

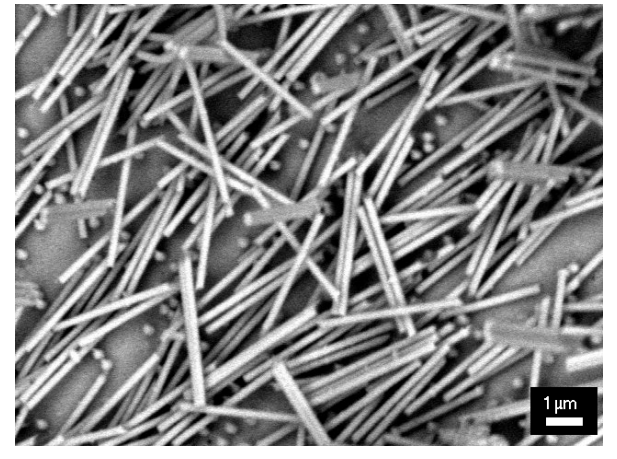

e)

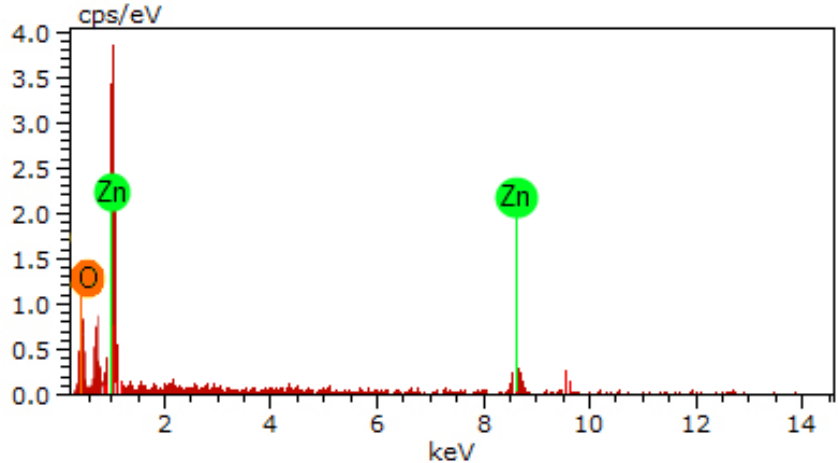

b)

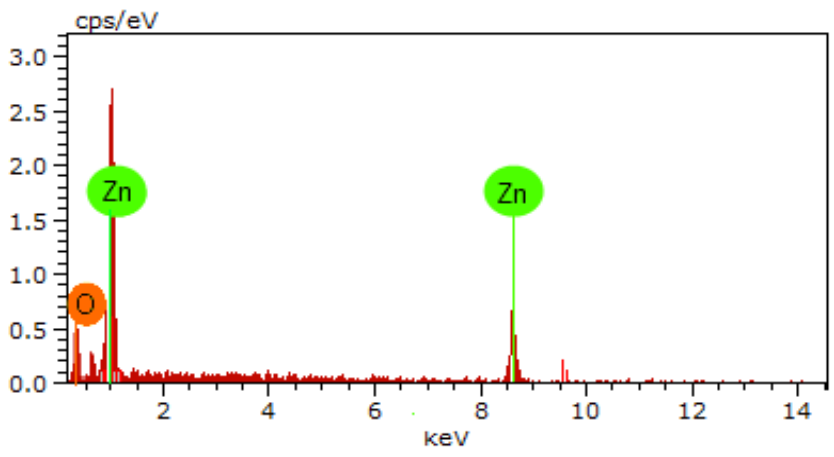

d)

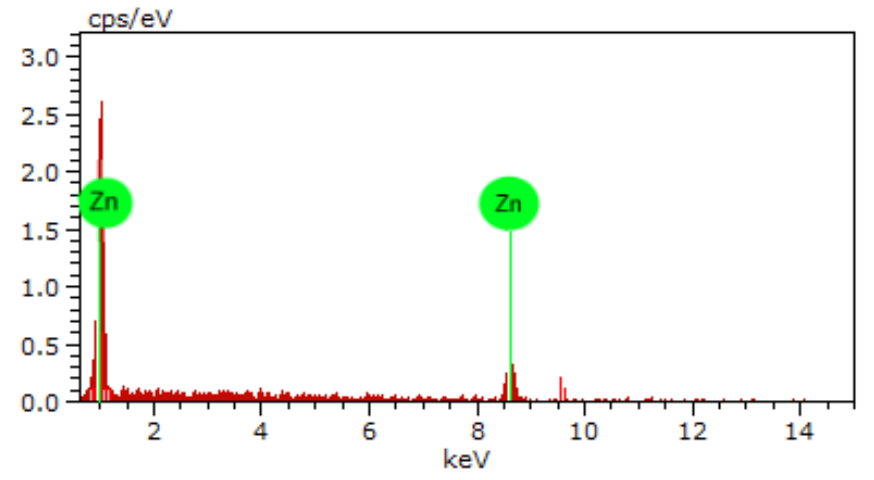

f)

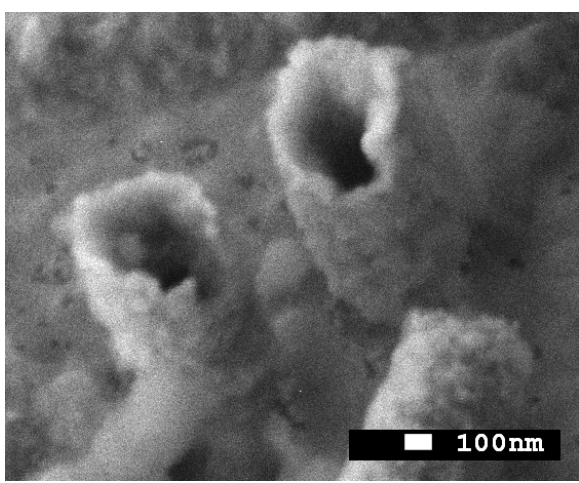

g)

Figure 4-SEM images of $\mathrm{Zn}$ nanotubes (a, c, e); EDA spectra of $\mathrm{Zn}$ nanotubes at $1.25 \mathrm{~V}(\mathrm{~b}), 1.5 \mathrm{~V}(\mathrm{~d})$ ), and at $1.75 \mathrm{~V}(\mathrm{f})$; SEM image of inner diameter of tubes $(\mathrm{g})$ 


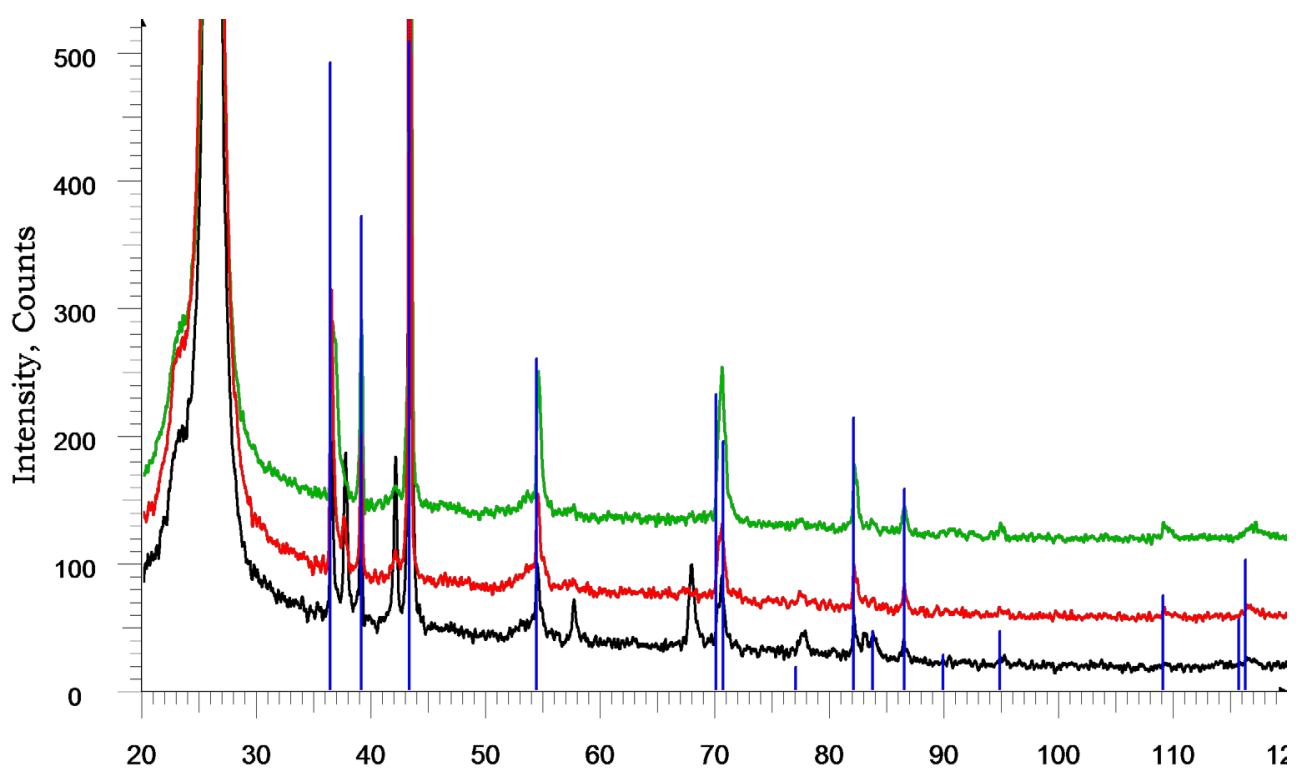

2 Theta, degrees
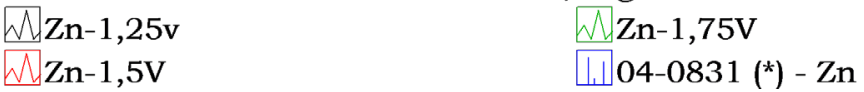

Figure 5 - X-ray diffractogramms of investigated $\mathrm{Zn}$ nanotubes

data from energy dispersive analysis. Table 2 shows X-ray data of tested samples, parameters $a$ and $c$ of lattice and results of calculation of average sizes of crystallites by Scherrer equation (1):

$$
\tau=\frac{k \lambda}{\beta \cos \theta},
$$

where $k=0.9$ is a dimensionless coefficient of particle shape (Scherrer constant), $\lambda=1.54 \AA$ is $\mathrm{X}$-rays wavelength, $\beta$ is a half-width at half-maximum (FWHM); $\vartheta$ is an angle of diffraction (Bragg angle). Size of crystallites was calculated for peaks (002), (100), (101), (112), (200), (201), (203). After that, an average value was calculated (Table 2 ).

Calculations of average sizes of crystallites showed that decrease of intensity of $\mathrm{ZnO}$ oxide phase leads to decrease of sizes of crystallites from $41.52 \mathrm{~nm}$ for $1.25 \mathrm{~V}$ to $29.34 \mathrm{~nm}$ for $1.75 \mathrm{~V}$.

Texture coefficients were calculated by Harris formula (2):

$$
T C(h k l)=\frac{I(h k l)}{I_{0}(h k l)} / \frac{1}{n} \sum \frac{I(h k l)}{I_{0}(h k l)},
$$

where I(hkl) - relative intensity obtained experimentally; $I_{0}(h k l)$ - relative intensity corresponding to given plane according to base JCPDS; $n$ - the number of planes. Table 3 shows results of calculations.

Calculations of texture coefficients in nanotubes synthesized at potential difference of $1.75 \mathrm{~V}$ show that texture of polycrystals becomes multicomponent (101), (112), (201).
Table 2 - Data from calculations of average sizes of crystallites

\begin{tabular}{|c|l|c|c|}
\hline $\begin{array}{c}\text { Name of } \\
\text { sample }\end{array}$ & \multicolumn{1}{|c|}{$\begin{array}{c}\text { Parameters of cell } \\
\text { sample }\end{array}$} & $\begin{array}{c}\text { Data by base } \\
\text { (No. of card) }\end{array}$ & $\begin{array}{c}\text { Average } \\
\text { size of } \\
\text { crystallites, } \\
\mathrm{nm}\end{array}$ \\
\hline Zn 1.25 V & $\begin{array}{l}\text { Phase Zn (hexagonal } \\
\text { primitive cell): } \\
\mathrm{a}=(2.6650 \pm 0.0008) \AA \\
\mathrm{c}=(4.9273 \pm 0.0050) \AA\end{array}$ & $\begin{array}{l}\text { No. 04-0831: } \\
\mathrm{a}=2.665 \AA \\
\mathrm{c}=4.947 \AA\end{array}$ & $41.52 \pm 1.3$ \\
\hline Zn 1.50 V & $\begin{array}{l}\text { Phase Zn (hexagonal } \\
\text { primitive cell): } \\
\mathrm{a}=(2.6648 \pm 0.0009) \AA \\
\mathrm{c}=(4.9289 \pm 0.0053) \AA\end{array}$ & $\begin{array}{l}\text { No. } 04-0831: \\
\mathrm{a}=2.665 \AA \\
\mathrm{c}=4.947 \AA\end{array}$ & $37.15 \pm 1.5$ \\
\hline Zn 1.75 V & $\begin{array}{l}\text { Phase Zn (hexagonal } \\
\text { primitive cell): a }= \\
(2.6655 \pm 0.0006) \AA, \\
\mathrm{c}=(4.9231 \pm 0.0045) \AA\end{array}$ & $\begin{array}{c}\text { No. } 04-0831: \\
\mathrm{a}=2.665 \AA, \\
\mathrm{c}=4.947 \AA\end{array}$ & $29.34 \pm 1.2$ \\
\hline
\end{tabular}

Table 3 - Data of textural coefficients

\begin{tabular}{|c|c|c|c|c|}
\hline \multirow{2}{*}{$2 \theta$ o } & \multirow{2}{*}{$(\mathrm{hkl})$} & \multicolumn{3}{|c|}{$\mathrm{TC}(\mathrm{hkl})$} \\
\cline { 3 - 5 } & & $\mathrm{Zn}_{73} \mathrm{O}_{27}$ & $\mathrm{Zn}_{86} \mathrm{O}_{14}$ & $\mathrm{Zn}_{100}$ \\
\hline 36.296 & 002 & 0.840061 & 0.724619 & 0.703054 \\
\hline 38.992 & 100 & 1.045106 & 0.475531 & 1.047087 \\
\hline 43.231 & 101 & 3.408915 & 1.264461 & 3.278464 \\
\hline 82.102 & 112 & 0.535298 & 0.363604 & 1.083193 \\
\hline 83.765 & 200 & 0.356127 & - & 0.6091 \\
\hline 86.557 & 201 & 0.58458 & 0.218961 & 1.10919 \\
\hline 109.12 & 203 & - & - & 0.169913 \\
\hline
\end{tabular}




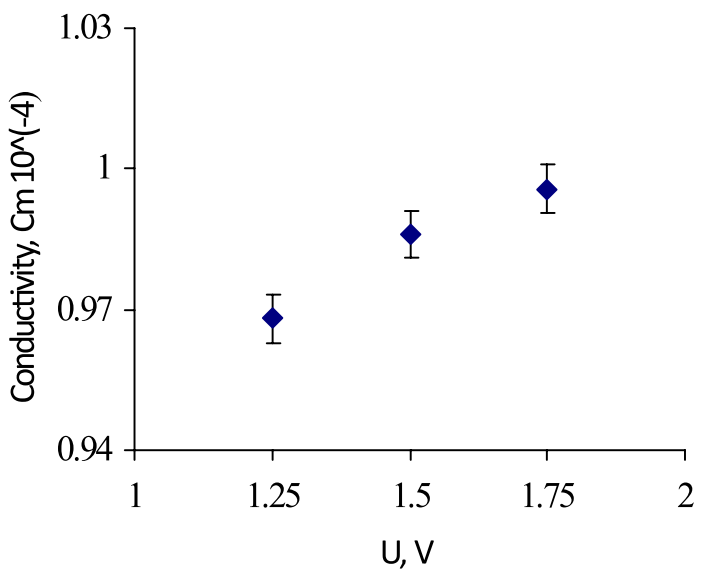

a)

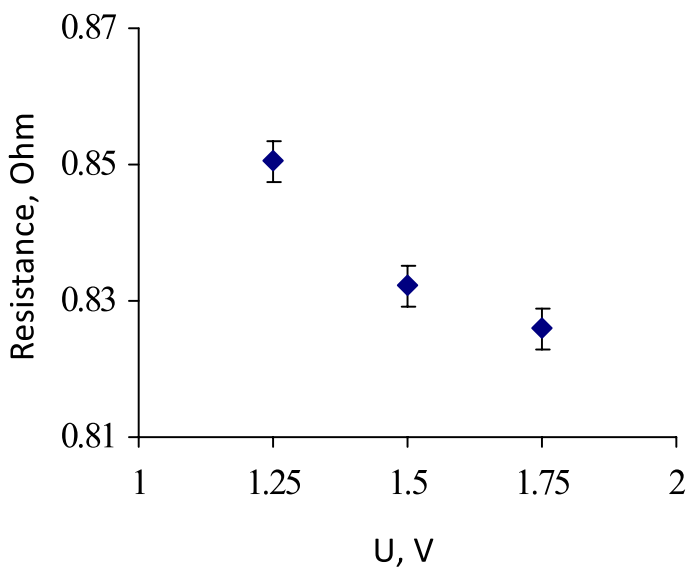

b)

Figure 6 - Dependencies of conductivity change on potential difference (a) and resistance change on potential difference (b)

The shape of conducting surface is important because it affects the movement of electric charge in a material. The shape of particles that conduct electricity may be, for example, acicular, cylindrical, plate, tubular or spherical. These are idealized shapes of particles; actual shape can deviate more or less strongly from the ideal, depending on manufacturing process. Conducting surface in the form of array of identical cylinders was investigated in this paper. Volt-ampere characteristics were recorded from array of nanotubes with area of $1.5 \mathrm{~cm}^{2}$. The scheme of the setup for measuring volt-ampere characteristics is following: a sample with deposited nanotubes is placed between two copper plates, which cover only the part of sample with nanotubes in film. Then plates are connected to current source with series connection of ammeter. Since PET-based template matrices are dielectric, they do not contribute to volt-ampere characteristics (VAC) throughout measuring range of voltage of matrix.

Figure 6 shows graphs of dependence of resistance changes and conductivity on potential difference applied during process of deposition.

The conductivity of $\mathrm{Zn}$ nanotubes was calculated by the formula (3):

$$
\sigma=\frac{d I}{d U} \frac{l}{A},
$$

where I - length of nanotubes, $d I / d U$ - slope of $I-U$, $A$ - area of conducting surface calculated using the formula (4):

$$
A=\left(S_{\text {out }}-S_{\text {inn }}\right) * N * h
$$

where $S_{\text {out }}$ - area of outer ring of nanotubes (under section of nanotubes perpendicular to its axis), $S_{\text {inn }}$ - area of inner ring, $N$-pore density (fluence of irradiation), $h$-height of nanotubes.

Figure 6 demonstrates that, according to EDA and XRD analysis, the crystal structure changes with increase of potential difference during deposition of $\mathrm{Zn}$ nanotubes and change in crystal structure leads to increasing conductivity. Change of conductive properties of $\mathrm{Zn}$ nanotubes can be explained by heterogeneity of crystallites formed during electrochemical deposition. The number of defects that hinder the flow of electrons decreases with decrease of average size of crystallites in nanotubes. The number of defects directly affects conductive properties of $\mathrm{Zn}$ nanotubes.

\section{Conclusion}

This paper describes the method of growth of Zn-based nanotubes using electrochemical deposition. Track-etched PETbased membranes with pore density of $4.0 \mathrm{E}+07$, thickness of 12 microns and pore diameters of $380 \mathrm{~nm}$, were used as templates. Characterization of the structural features of obtained nanotubes was carried out by SEM, EDA and XRD. According to EDA analysis, formation of oxide phase of zinc with atomic ratio $\mathrm{Zn}_{73} \mathrm{O}_{27}$ occurs as a results of process of deposition at potential difference $1.25 \mathrm{~V}$. Oxide phase is displaced with increase of applied potential difference, which is due to the predominance of half of redox potential of $\mathrm{Zn}$ reduction over the formation of oxide phase $\mathrm{ZnO}$. Thus, pure zinc nanotubes without additives of oxide phases can be prepared by electrochemical deposition at potential difference of $1.75 \mathrm{~V}$. Calculations of average sizes of crystallites show that decrease of intensity of $\mathrm{ZnO}$ oxide phase leads to the decrease of crystallites sizes from $41.52 \mathrm{~nm}$ for $1.25 \mathrm{~V}$ to 29.34 $\mathrm{nm}$ for $1.75 \mathrm{~V}$. The number of defects that hinder the flow of electrons decreases with decrease of average size of crystallites in nanotubes. The number of defects directly affects conductive properties of $\mathrm{Zn}$ nanotubes. Thus, production of $\mathrm{Zn}$ nanotubes opens up an opportunity of their application as semiconductor materials in electronic and optoelectronic circuits.

\section{Acknowledgement}

This research was done in the framework of the program of targeted funding from the Ministry of Education and Science of the Republic of Kazakhstan No. 561 from 07.04.2015. 


\section{References (GOST)}

1 Park W.I., Kim J.S., Yi G.C., Lee H.J. ZnO nanorod logic circuits // Advanced Materials. - 2005. - Vol.17, Is.11. - P.1393-1397.

2 Mofor A.C., Bakin A., Chejarla U., Schlenker E., El-Shaer A., Wagner G., Boukos N., Travlos A., Waag A. Fabrication of ZnO nanorodbased p-n heterojunction on SiC substrate // Superlattices Microstruct. - 2007. - Vol.42, Is.1. - P.415-420.

3 Park D.J., Lee J.Y., Kim D.C., Mohanta S.K., Cho H.K. Defects in interfacial layers and their role in the growth of ZnO nanorods by metallorganic chemical vapor deposition // Applied Physics Letters. - 2007. - Vol.91. - No.143115.

4 Wu X.F., Xu C.X., Zhu G.P., Ling Y.M. ZnO nanorods produced by the method of arc discharge // Chinese Physics Letters. -2006. - Vol.23, Is.8. - No.2165.

5 Han X.H., Wang G.Z., Tao Q., Cao W.L., Liu R.B., Zou B.S., Hou J.G. Ultraviolet lasing and time-resolved photoluminescence of well-aligned ZnO nanorod arrays // Applied Physics Letters. - 2005. - Vol.86, Is22. - No.223106.

6 Park H.K., Yang B.S., Park S., Kim M.S., Shin J.C., Heo J. Purge-time-dependent growth of ZnO thin films by atomic layer deposition // Journal of Alloys and Compounds. - 2014. - Vol.605, Is.25. - P.124-130.

7 Ramanathan S., Patibandla S., Bandyopadhyay S., Edwards J.D., Anderson J. Fluorescence and infrared spectroscopy of electrochemically self assembled ZnO nanowires: evidence of the quantum confined Stark effect // Journal of Materials Science: Materials in Electronics. - 2006. - Vol.17, Is.9. - P.651-655.

8 Beard M.C., Turner G.M., Schmuttenmaer C.A. Size-dependent photoconductivity in CdSe nanoparticles as measured by timeresolved terahertz spectroscopy // Nanoletters. - 2002. - Vol.2, Is.9. - P.983-987.

9 Olvera M. de la L., Maldonado A., Asomoza R., Castanedo-Pe'rez R., Torres-Delgado G., Can etas-Ortega J. Conductive and transparent ZnO:Al thin films obtained by chemical spray // Journal of Materials Science: Materials in Electronics. - 2000. - Vol.11, Is.5. - P.383-387.

10 Murali K.R., Srinivasan K., Trivedi D.C. Vacuum evaporated CdSe thin films and their characteristics // Materials Letters. - 2005. - Vol.59, Is.1. - P.15-18.

11 Studenikin S.A., Golege N., Cocivera M. Optical and electrical properties of undoped ZnO films grown by spray Pyrolysis of zinc nitrate solution // Journal of Applied Physics. - 1998. - Vol.83, Is.4. - No.2104.

12 Nielsch K., Wehrspohn R.B., Barthel J., Kirschner J., Gosele U., Fischer S.F., Kronmuller H. Hexagonally ordered $100 \mathrm{~nm}$ period nickel nanowire arrays // Applied Physics Letters. - 2001. - Vol.79. - No.1360.

13 Edmondson M.J., Zhou W.Z., Sieber S.A., Jones I.P., Gameson I., Anderson P.A., Edwards P.P. Electron-beam induced growth of bare silver nanowires from zeolite crystallites // Advanced Materials. - 2001. - Vol.13, Is.21. - P.1608-1611.

14 Fan Z.Y., Dutta D., Chien C.J., Chen H.Y., Brown E.C., Chang P.C., Lua J.G. Electrical and photoconductive properties of vertical ZnO nanowires in high density arrays // Applied Physics Letters. - 2006. - Vol.89. - No.213110.

15 Martinson A.B.F., Elam J.W., Hupp J.T., Pellin M.J. ZnO nanotube based dye-sensitized solar cells // Nano Letters. - 2007. - Vol.7, Is.7. - P.2183-2187.

16 Apel P.Y., Blonskaya I.V., Oganessian V.R., Orelovitch O.L., Trautmann C. Morphology of latent and etched heavy ion tracks in radiation resistant polymers polyimide and poly(ethylene naphthalate) // Nuclear Instruments and Methods in Physics Research Section B: Beam Interactions with Materials and Atoms. - 2001. - Vol.185., Is.1-4. - P.216-221.

17 Vilensky A.I., Zagorski D.L., Apel P.Y., Pervov N.V., McHedlishvili B.V., Popok V.N., Mel'nik N.N. Thermal regression of latent tracks in the polymer irradiated by high energy heavy ions // Nuclear Instruments and Methods in Physics Research Section B: Beam Interactions with Materials and Atoms. - 2004. - Vol.218. - P.294-299.

18 Shao P., J G., Chen P. Gold nanotube membranes: Preparation, characterization and application for enantioseparation // Journal of Membrane Science. - 2005. - Vol.255, Is.1-2. - P.1-11.

\section{References}

1 Park WI, Kim JS, Yi GC, Lee HJ (2005) Adv Mater 17:1393-1397. http://dx.doi.org/10.1002/adma.200401732

2 Mofor AC, Bakin A, Chejarla U, Schlenker E, El-Shaer A (2007) Superlattices Microstruct 42:415-420. http://dx.doi.org/10.1016/j. spmi.2007.04.027

3 Park DJ, Lee JY, Kim DC, Mohanta SK, Cho HK (2007) Appl Phys Lett 91:143115. http://dx.doi.org/10.1063/1.2794418

4 Wu XF, Xu CX, Zhu GP, Ling YM (2006) Chinese Phys Lett 23:2165. http://dx.doi.org/10.1088/0256-307X/23/8/056

5 Han XH, Wang GZ, Tao Q, Cao WL, Liu RB, Zou BS, Hou JG (2005) Appl Phys Lett 86:223106. http://dx.doi.org/10.1063/1.1941477

6 Park HK, Yang BS, ParkS, Kim MS, Shin JC, Heo J (2014) J Alloy Compd 605:124-130. http://dx.doi.org/10.1016/j.jallcom.2014.03.169

7 Ramanathan S, Patibandla S, Bandyopadhyay S, Edwards JD, Anderson J (2006) J Mater Sci-Mater El 17:651-655. http://dx.doi. org/10.1007/s10854-006-0021-4

8 Beard MC, Turner GM, Schmuttenmaer CA (2002) Nanoletters 9:983-387. http://dx.doi.org/10.1021/nl0256210

9 Asomoza R, Malodonado H, Olvera MD (2000) J Mater Sci-Mater El 11:383-387. http://dx.doi.org/10.1023/A:1008990431442 
10 Murali KR, Srinivasan K, Trivedi DC (2005) Mater Lett 59:15-18. http://dx.doi.org/10.1016/j.matlet.2004.09.006

11 Studenikin SA, Golege N, Cocivera M (1998) J Appl Phys 83:2104-2111. http://dx.doi.org/10.1063/1.368295

12 Nielsch K, Wehrspohn RB, Barthel J, Kirschner J, Gosele U, Fischer SF (2001) Appl Phys Lett 79:1360. http://dx.doi. org/10.1063/1.1399006

13 Edmondson MJ, Zhou WZ, Sieber SA, Jones IP, Gameson I, Anderson PA (2001) Adv Mater 13:1608-1611. http://dx.doi.org/09359648/01/2111-1610

14 Fan ZY, Dutta D, Chien CJ, Chen HY, Brown EC, Chang PC, Lua JG (2006) Appl Phys Lett 89:213110. http://dx.doi. org/10.1063/1.2387868

15 Martinson ABF, Elam JW, Hupp JT, Pellin MJ (2007) Nano Lett 7:2183-2187. http://dx.doi.org/10.1021/n/070160

16 Apel PYu, Blonskaya IV, Oganessiana VR, Orelovitcha OL, Trautmannb C (2001) Nucl Instrum Meth B 185:216-221. http://dx.doi. org/10.1016/S0168-583X(01)00967-3

17 Vilensky Al, Zagorski DL, Apel PY (2004) Nucl Instrum Meth B 218:294-299. http://dx.doi.org/10.1016/j.nimb.2003.12.066

18 Shao P, JI G, Chen P (2005) J Memb Sci 255:1-11. http://dx.doi.org/10.1016/j.memsci.2005.01.018 